\title{
Chemical Composition Related to Antimicrobial Activity of Moroccan Nigella sativa L. Extracts and Isolated Fractions
}

\author{
Salima Tiji $\mathbb{D}$, ${ }^{1}$ Yahya Rokni, ${ }^{2}$ Ouijdane Benayad $\left(\mathbb{D},{ }^{1}\right.$ Nassima Laaraj, \\ Abdeslam Asehraou $\mathbb{D}^{2},{ }^{2}$ and Mostafa Mimouni $\mathbb{D}^{1}$ \\ ${ }^{1}$ Team of Electrochemistry, Laboratory of Applied Chemistry, Faculty of Sciences Oujda, University Mohammed First, \\ Oujda, Morocco \\ ${ }^{2}$ Laboratory of Bio-Resources, Biotechnology, Ethno-Pharmacology and Health, Faculty of Sciences Oujda, \\ University Mohammed First, Oujda, Morocco
}

Correspondence should be addressed to Salima Tiji; salimatiji@gmail.com and Mostafa Mimouni; mimouniosrn@gmail.com

Received 5 May 2021; Accepted 7 October 2021; Published 23 October 2021

Academic Editor: Manzoor A. Rather

Copyright $\odot 2021$ Salima Tiji et al. This is an open access article distributed under the Creative Commons Attribution License, which permits unrestricted use, distribution, and reproduction in any medium, provided the original work is properly cited.

Background. Nigella sativa L. (NS) is an aromatic and medicinal plant commonly used in Mediterranean cuisine. Its grains contain a large amount of fixed oil and have many therapeutic virtues and medicinal properties (antioxidant, antidiabetic, antimicrobial, and anticancer). Aim. The aim of this work is to study the antimicrobial activity of Nigella sativa L. extracts and separated fractions on various pathogenic strains and to correlate that with its chemical composition. Methods. Extracts from Moroccan Nigella sativa seeds were extracted using successive organic solvents, and their hexane and acetone extracts were separated by column chromatography. The chemical composition of extracts, fractions, and essential oil was determined by GC-MS and HPLC-DAD. Extracts and fractions were evaluated for antimicrobial activity through disk diffusion against Gram-positive bacteria (Staphylococcus aureus, Bacillus cereus, and Listeria innocua), Gram-negative bacteria (Escherichia coli and Pseudomonas aeruginosa), and yeast (Candida pelliculosa) for $1 \mathrm{mg} / \mathrm{mL}$ concentration. Bacterial strains were followed to study their behaviors over time in different concentrations. The minimum inhibitory concentration of Nigella sativa essential oil was determined against Staphylococcus aureus, Bacillus cereus, Escherichia coli, and Candida albicans. Results and Conclusion. Although hexane extract was active against both types of bacteria (Gram+ and Gram-), some of its fractions were specifically active against only one type. Fraction (SH4) had the highest activity (15 mm inhibitory diameter). Acetone extract was nonactive but surprisingly resulted in specific active fractions, and the most interesting one was (SA7) that had an inhibitory diameter of $13 \mathrm{~mm}$. This antibacterial effect was related to fatty acids (linoleic and palmitic acids) in (SH4) and 17 pentatriacontene in (SA7). Moreover, the antifungal activity of hexane fractions $(10-13 \mathrm{~mm})$ was higher than hexane extract $(8 \mathrm{~mm})$, but for acetone, it was the opposite. Acetone extract had a higher activity $(18 \mathrm{~mm})$ than its fractions $(8-12 \mathrm{~mm})$, except for (SA7) $(19 \mathrm{~mm})$. Those inhibitions were attributed to gallic acid, cysteine, and apigenin in acetone extract and cysteine with ascorbic acid in fraction (SA7). Antifungal activity of the essential oil was more pronounced than the antibacterial one. Indeed, determined MICs in the first case were on the microgram scale (MIC $=8 \mu \mathrm{g} / \mathrm{mL}$, Candida albicans), while in the second case, they were on the milligram scale (MIC $=0.96 \mathrm{mg} / \mathrm{mL}$ for Staphylococcus aureus, $0.5 \mathrm{mg} / \mathrm{mL}$ for Bacillus cereus, and $0.68 \mathrm{mg} / \mathrm{mL}$ for Escherichia coli). This antifungal activity was attributed to three major compounds beta-cymene, alpha-thujene, origanene, and thymoquinone. Results of strains behavior over time at different concentrations of the fractions showed all the curves went through a maximum around 20 hours and had a delay of expression of 5 hours at the start. Taking all results into count, Nigella sativa L. extracts and/or derived principles could form promising antimicrobial agents for therapeutical and industrial uses. 


\section{Introduction}

Commonly called black cumin, Nigella sativa (NS) is a yearly cool temperature resistant plant in the Ranunculaceae family. NS seeds are used in traditional medicine and as a culinary spice throughout its range from the Mediterranean basin to India. In Morocco, the plant is cultivated in coastal areas in July and traditionally used to treat asthma, diabetes, and other inflammatory diseases [1]. Indeed, research has confirmed an abundance of secondary metabolites [2]. The seeds are gaining popularity for their medicinal and dietary uses, and many cooperatives view the plant as an exploitable source of oil as the argan tree [3]. In fact, Moroccan Nigella sativa produces high quality oil even when compared to other variants [4]. Consequently, large-scale cultivation is being considered, despite considerable variation in yield [5].

Many studies have explored the biological properties of NS [6-8]. The plant has antibacterial effects against both Gram-positive and Gram-negative bacteria [9]. In addition, the seeds have an important activity against multidrug resistant bacterial strains [10]. NS seeds also have antifungal properties because of thymoquinone [11].

Previous studies of NS focused mostly on seed extracts or essential oils $[12,13]$. The diversity of chemical compounds in the extracts makes attribution of antimicrobial activity to specific compounds difficult, especially when considering toxicity. Hepatic damage can occur with an aqueous extract [14] and metabolic changes with a lipid extract [15]. Consequently, the specific chemical(s) that imparts antimicrobial properties to NS must be separated and purified for exploitation.

In this study, we investigate the antimicrobial activity of Moroccan NS fractions separated from hexane and acetone extracts and the essential oil. The level of inhibition by the fractions was evaluated against Gram-positive and Gramnegative bacteria and fungi strains and the impact of the separation process was evaluated.

\section{Materials and Methods}

2.1. Plant and Material. Nigella sativa seeds (NS) were purchased from a local market in Oujda, Morocco. Organic analytical grade np solvents $(98.9 \%)$, cycloheximide, and tetracycline were supplied by Sigma-Aldrich. Silica gel was from Fluka. Mueller-Hinton medium (BIOKAR, France) and potato dextrose (BIOKAR, France) were used for microbial cultures of bacteria and yeast, respectively. The microbial strains used as targets were Escherichia coli, Pseudomonas aeruginosa, Staphylococcus aureus, Listeria innocua, Candida pelliculosa, and Candida albicans.

2.2. Extractions. Nigella sativa (NS) seeds were cleaned and reduced by a blender into a powder of $5 \mu \mathrm{m}$. The powder was added to warm organic solvents $\left(50^{\circ} \mathrm{C}\right)$ with a Soxhlet apparatus and a liquid-seed ratio of 7:1. Hexane and acetone were successively used for the extraction, and organic extracts obtained were concentrated under a vacuum rotatory at $40^{\circ} \mathrm{C}$ and conserved at a low temperature $\left(-4^{\circ} \mathrm{C}\right)$.
The essential oil was extracted by hydrodistillation using hexane extract produced at $50^{\circ} \mathrm{C}$. Hexane extract was mixed with water and then distillated for three hours at $40^{\circ} \mathrm{C}$. The essential oil was collected through Clevenger and stored at $-4^{\circ} \mathrm{C}$.

2.3. Separation of Extracts. Hexane and acetone extracts were fractioned using column chromatography. Hexane extract was separated using a silica gel column with $20 \%$ hexane $/ 80 \%$ dichloromethane eluents. Acetone extract was separated using silica gel column chromatography and a 50\% cyclohexane $/ 50 \%$ dichloromethane eluent system [7]. The separation of both extracts was at ambient temperature and pressure.

\subsection{Characterization Analysis}

2.4.1. Gas Chromatography Coupled to Mass Spectroscopy (GC-MS) Analysis. Gas chromatography (GC) analysis was performed in Shimadzu GCMS-QP2010 through GC column (30 $\mathrm{m} \times 0.25 \mathrm{~mm}, 0.25 \mu \mathrm{m})$. Helium gas was utilized as carried gas, and ionization temperature was $200^{\circ} \mathrm{C}$. Time analysis for extract and fractions was $28 \mathrm{~min}$ and essential oil analysis time was $11 \mathrm{~min}$. The compound characterization was executed based on retention time and mass fragments spectral of our samples by being compared to those of the reference standards through computer library NIST147.LIB [16].

2.4.2. High Performance Liquid Chromatography Coupled to a Diode Array Detector (HPLC-DAD) Analysis. HPLC analysis was completed using Waters e2695. A C18 column $(5 \mu \mathrm{m}, 250 \times 4.6 \mathrm{~mm})$ was used for analytical separation. Eluents (A: water/acetic acid $(2 \% \mathrm{v} / \mathrm{v})$ and B: acetonitrile $\mathrm{pH}=2.6$ ) were used in gradient mode. The separation was performed under a flow rate of $0.9 \mathrm{~mL} / \mathrm{min}$ following Mechraoui et al.'s method [17]. The injection volume of samples was $20 \mu \mathrm{l}$, and the column temperature was set to $25^{\circ} \mathrm{C}$. The components were observed by diode array detector (DAD) at $280-365 \mathrm{~nm}$. [17]. Sample chromatograms were used to compare standard referring to retention time and $\lambda$ max. The chromatographic characterization was carried out twice and results were median.

\subsection{Antibacterial Activity}

2.5.1. Disk Diffusion Test. Antibacterial activity was evaluated by an agar diffusion test, followed by the Abrigach et al.'s method [18]. Agar cultures were prepared with overnight bacterial cultures of $10^{8}$ cells $/ \mathrm{mL}$. Extracts and fractions at $10 \mathrm{mg} / \mathrm{mL}$ were aseptically positioned on sterile filter paper disks $(6 \mathrm{~mm})$ and on Petri plates. Papers were treated with gentamicin at $40 \mathrm{mg} / \mathrm{mL}$ as a standard antibiotic against bacteria. Dimethyl sulfoxide (DMSO) was used as the negative control. Plates with extracts and fractions were maintained at ambient temperature for prediffusion for two hours, and then the disk plates were incubated at $37^{\circ} \mathrm{C}$ for 24 hours $[19,20]$. After incubation, inhibition diameters were measured in millimeters. 
2.5.2. Quantitative Test. Antibacterial activity was performed on three bacterial strains (E. coli, P. aeruginosa, and L. innocua). The extract and fractions evaluated were ((FH), (SH2), (SH3), (SA7), and (SA8)). Different concentrations from 2 to $128 \mu \mathrm{g} / \mathrm{mL}$ were employed and the results were reported as optical density (OD) graphics.

2.5.3. Microdilution Test: Determination of Antibacterial MIC in Essential Oil. The antibacterial activity of the essential oil of NS was determined when using Hayes and Markovic's microdilution method [21]. $400 \mu \mathrm{L}$ of the essential oil was diluted in $1 \mathrm{~mL}$ DMSO. Serial concentration $(500 \mu \mathrm{g} / \mathrm{mL}$ to $1000 \mu \mathrm{g} / \mathrm{mL}$ ) dilutions were prepared and mixed with $2 \%$ of MHB (Mueller-Hinton Broth) medium and then inoculated with overnight culture $\left(10^{7} \mathrm{CFU} / \mathrm{mL}\right)$ of targets [22]. The cultures were then incubated at $37^{\circ} \mathrm{C}$ for $24 \mathrm{~h}$. The minimum inhibitory concentration (MIC) was defined using absorbance at $625 \mathrm{~nm}$, which refers to the turbidity caused by microorganism's growth. The MIC was obtained from samples showing total inhibition of bacterial growth. DMSO, used as negative control, could not inhibit bacterial strains [23].

\subsection{Antifungal Activity}

2.6.1. Disk Diffusion Test. The antifungal activity of extracts and fractions of NS was determined using Candida pelliculosa as a target, according to the Barros et al.'s [24] method. Sterile paper disks were positioned on potato dextrose agar (PDA) plates and $1 \%$ of strain suspension. Extracts and fractions at $10 \mu \mathrm{g} / \mathrm{mL}$ were prepared and incubated at $28^{\circ} \mathrm{C}$ five days. Cycloheximide $0.01 \%(w / v)(\mathrm{mg} /$ L) was the antifungal standard and the negative control was DMSO. Fungal activity results were evaluated for five days and were expressed by diameter of inhibition halo.

2.6.2. Microdilution Test: Determination of Antifungal MIC of Essential Oil. The antifungal activity of NS essential oil was performed using the Chebaibi et al.'s microdilution method [25]. Serial concentrations $(1 \mu \mathrm{g} / \mathrm{mL}$ to $32 \mu \mathrm{g} / \mathrm{mL})$ samples were prepared and added to the Candida albicans suspension and $2 \% \mathrm{MHB}$. Samples were incubated at $28^{\circ} \mathrm{C}$ for 48 hours. The MIC was determined using the concentration of completely inhibited microorganism growth.

\section{Results}

3.1. Extraction. Nigella sativa (NS) extractions were successively performed by hexane, chloroform, ethyl acetate, and acetone organic solvents using Soxhlet apparatus at $50^{\circ} \mathrm{C}$. The solvents were evaporated under vacuum rotary at $40^{\circ} \mathrm{C}$. Hexane extract gave a yield of $34.2 \%$ and acetone extract was represented by $2.03 \%$. Nigella sativa essential oil constituted $1.12 \%$ of hexane extract and $0.28 \%$ of NS seeds.

3.2. Separation of Hexane and Acetone Extracts. Hexane and acetone extracts were fractioned according to our previous work [7]. Hexane extract gave eight fractions (SH (1-8)) and acetone extract specified eleven fractions (SA (1-11)). Those specified fractions were the results of successive separations of the extract tell having single compounds.

3.3. Gas Chromatography-Mass Spectroscopy (GC-MS) Analysis. GC-MS was performed on the hexane esterified extract, the fractions from the hexane extract, and the essential oil.

The hexane esterified extract showed the presence of linoleic acid as the most abundant component (Figure 1). Palmitic acid represented a third of the fatty composition and both oleic acid and monoacetate constituted less than 3\% (Table 1).

Figure 2 shows the essential oil major constituents were $\beta$-cymene (37.76\%), $\alpha$-thujene (13.60\%), and thymoquinone (5.69\%). Other components represented less than 3\%. The volatile oil was distinguished by abundant hydrocarbonic and oxygenic monoterpenes (Table 2).

The hexane fractions were identified as fatty acids. Different compounds were characterized as described in our previous study [7] based on comparing retention time and mass fragments with standard. (SH1) major compounds were 17 bromopropanoic acid (9.3\%), 1-octadecanol (17.79\%), linoleic acid (18.29\%), heptadecanoic acid (11.02\%), and 9-octadecanoic acid (28.12\%). (SH2) had azelaic acid (9.44\%), laural dimethyl acetal (12.14\%), palmitic acid (4098.98\%), linoleic acid (17.10\%), and heptadecanoic acid (16.35\%). Fraction (SH3) had octadecanol as one major compound (87.32\%) and (SH4) had hexadecane 7.9-dimethyl (9.97\%), hexadecane (10.84\%), tricosanoic acid $(11.17 \%)$, and 17 pentatriacontene $(60.37 \%)$. The (SH5) had linoleic acid (92.54\%), and (SH6) had 1-octadecanol (47.22\%) and oleic acid (12.34\%). (SH7) presented heptadecane 2-methyl (11.68\%), 9-eicosene (16.82\%), palmitic acid (18.89\%), 9-tricosene (9.74\%), and linoleic acid (14.08\%). Finally, (SH8) had 9-eicosene (16.53\%), dichloroacetic acid (16.84\%), palmitic acid (24.91\%), octadecanol (13.23\%), and stearic acid (10.49\%). Only two fractions (SH3) and (SH5) had one major compound over 87\%; fractions ( $\mathrm{SH} 2),(\mathrm{SH} 4)$, and (SH6) had components around $50 \%$. Indeed, fractions of hexane extract shared many compounds such as palmitic acid, linoleic acid, and oleic acid (Table 3 ).

3.4. HPLC-DAD. The identification of the acetone extract and its fractions revealed interesting compounds. Major compounds included polyphenol derivatives. Before the column chromatography, separation, the acetone extract contained gallic acid as the most abundant constituent. Components such as thymoquinone, apigenin, naringenin, ascorbic acid, cysteine, rutin, quercetin, and kaempferol were also found in acetone extract with different proportionalities. After the separation, the compounds were purified and were concentrated in the fractions (Table 4). (SA1) had exclusively gallic acid while (SA2) had gallic acid, thymoquinone, and apigenin. Fractions (SA3) and (SA4) had mostly catechol and naringenin, but (SA7) had cysteine and rutin while (SA11) had quercetin and histidine. Overall, 


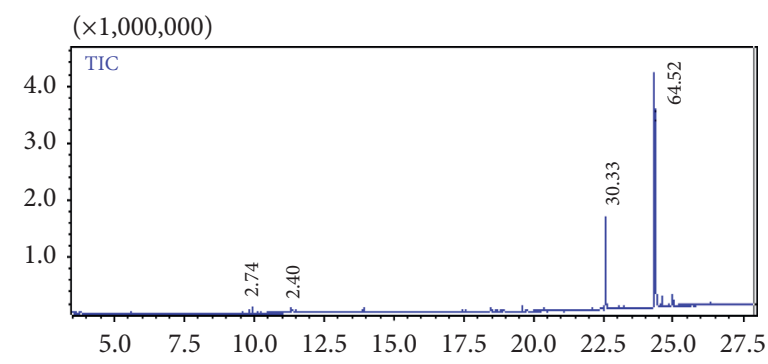

Figure 1: GC chromatogram of esterified hexane extract.

TABLE 1: Hexane extract identification by GC-MS.

\begin{tabular}{lccc}
\hline Peak & Compound & RT $(\min )$ & Area $(\%)$ \\
\hline 1 & Oleic acid & 9.93 & 2.74 \\
2 & Monoacetate, 1,2,3-propanetriol & 11.31 & 2.40 \\
3 & Palmitic acid & 22.58 & 30.33 \\
4 & Linoleic acid & 24.33 & 64.52 \\
\hline
\end{tabular}

RT, retention time; area, percentage obtained by electronic integration measurement using a mass detector RT trace. RT, retention time.

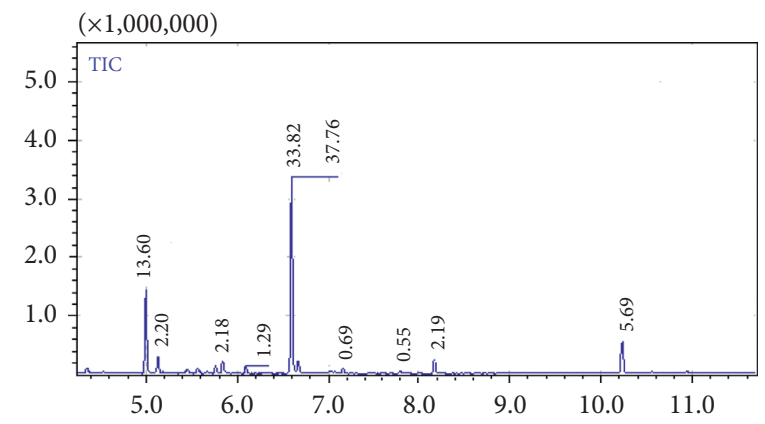

FIgURE 2: GC chromatogram of NS essential oil.

TABLe 2: NS essential oil characterization by GC-MS.

\begin{tabular}{lccc}
\hline Peak & Compound & RT (min) & Concentration \\
\hline 1 & Alpha-Thujene, origanene, or 3-thujene & 5.00 & 5.13 \\
2 & Alpha-Pinene & 5.84 & 13.60 \\
3 & Beta-Pinene & 6.10 & 2.20 \\
4 & 1,2,4-Trimethylbenzene or pseudocumene, Psi-cumene & 6.60 & 1.18 \\
5 & Beta-Cymene & 7.15 & 37.76 \\
6 & Gamma-Terpinene & 7.79 & 0.69 \\
7 & Lilac aldehyde & 8.17 & 0.55 \\
8 & 2-Cyclohexen-1-ol, 2-methyl-5-(1-methylethyl)-, (1S-cis) & 10.23 \\
9
\end{tabular}

acetone fractions were mostly well separated and presented one, two, or three compounds in each fraction.

\subsection{Determination of Antibacterial Activity by Disk Diffusion} Assay. The hexane extract (FH) and its fractions (SH1-9) presented a notable inhibitory effect on bacterial strains (Table 5), but visibly at lower levels than those obtained with tetracycline. Fractions (SH1) and (SH2) affected Grampositive and -negative bacteria respectively with diameter values ranges of $8-10 \mathrm{~mm}$ and $10-11 \mathrm{~mm}$. (SH3), (SH6), and (SH7) inhibited Gram-positive bacteria (8-12 mm), while (SH4) and (SH5) inhibited Gram-negative bacteria (12-15 $\mathrm{mm}$ and $9-10 \mathrm{~mm}$, respectively). The antibacterial activity of (SH1), (SH2), (SH3), (SH6), (SH7), and (SH8) was moderate on both Gram-positive and Gram-negative strains and (SH4) was high against Gram-positive strains. NS hexane extract presented high activity towards L. innocua $(12 \mathrm{~mm})$ and medium activity towards $S$. aureus $(10 \mathrm{~mm})$ and $E$. coli $(11 \mathrm{~mm})$. 
TABLE 3: Fractions of hexane extract identified by GC-MS.

\begin{tabular}{|c|c|c|c|c|}
\hline Fraction & Peak number & Compound & $\mathrm{RT}(\min )$ & Area $(\%)$ \\
\hline \multirow{8}{*}{ (SH1) } & 1 & 2.4-Decadienal & 15.11 & 4.95 \\
\hline & 2 & Lauric acid & 18.68 & 1.87 \\
\hline & 3 & Palmitic acid & 22.61 & 8.64 \\
\hline & 4 & 17 bromopropanoic acid & 23.26 & 9.3 \\
\hline & 5 & 1-Octadecanol & 23.58 & 17.79 \\
\hline & 6 & Linoleic acid & 24.36 & 18.29 \\
\hline & 7 & Heptadecanoic acid & 24.64 & 11.02 \\
\hline & 8 & 9-Octadecanoic acid (Z), 2-butoxyethyl ester & 25.79 & 28.12 \\
\hline \multirow{8}{*}{$(\mathrm{SH} 2)$} & 1 & 8-Hydroxyoctanoic acid & 16.23 & 2.61 \\
\hline & 2 & Methyl azelaaldehydate & 16.77 & 2.60 \\
\hline & 3 & Azelaic acid & 18.26 & 9.44 \\
\hline & 4 & Laural dimethyl acetal & 18.89 & 12.14 \\
\hline & 5 & Palmitic acid & 22.62 & 40.98 \\
\hline & 6 & Linoleic acid & 24.37 & 17.10 \\
\hline & 7 & 8-Octadecenoic acid & 24.43 & 1.25 \\
\hline & 8 & Heptadecanoic acid & 24.62 & 16.35 \\
\hline \multirow{4}{*}{ (SH3) } & 1 & 2.4-Decadienal & 15.24 & 1.70 \\
\hline & 2 & Palmitic acid, methyl ester & 22.60 & 5.65 \\
\hline & 3 & 1-Octadecanol & 23.84 & 87.32 \\
\hline & 4 & Oleic acid, methyl ester & 24.34 & 5.31 \\
\hline \multirow{5}{*}{ (SH4) } & 1 & 7,9-Dimethylhexadecane & 15.17 & 9.97 \\
\hline & 2 & Hexadecane & 18.13 & 10.84 \\
\hline & 3 & Tricosanoic acid & 22.58 & 11.17 \\
\hline & 4 & 17 pentatriacontene & 24.59 & 60.37 \\
\hline & 5 & Lignocerol & 24.79 & 7.62 \\
\hline \multirow{5}{*}{ (SH5) } & 1 & 2.6.11.15-Tetramethyl hexadecane & 17.55 & 0.29 \\
\hline & 2 & 9-Eicosene $(\mathrm{E})$ & 18.78 & 1.79 \\
\hline & 3 & Palmitic acid, methyl ester & 22.60 & 2.65 \\
\hline & 4 & (Z)-9-tricosene & 23.28 & 2.70 \\
\hline & 5 & Linoleic acid & 24.05 & 92.54 \\
\hline \multirow{9}{*}{ (SH6) } & 1 & Eicosane & 18.13 & 2.19 \\
\hline & 2 & Dichloroacetic acid, heptadecyl ester & 18.77 & 4.08 \\
\hline & 3 & 9-Tricosene & 21.14 & 5.12 \\
\hline & 4 & Palmitic acid, methyl ester & 22.60 & 4.09 \\
\hline & 5 & 1-(+)-Ascorbic acid 2.6-dihexadecanoate & 23.03 & 14.37 \\
\hline & 6 & 9-Tricosene & 23.28 & 6.60 \\
\hline & 7 & 1-Octadecanol & 23.91 & 47.22 \\
\hline & 8 & Oleic acid & 24.81 & 12.34 \\
\hline & 9 & 9-Hexacosene & 25.24 & 3.95 \\
\hline \multirow{10}{*}{ (SH7) } & 1 & 2.3-Dimethylhexadecane & 15.18 & 6.11 \\
\hline & 2 & 8-Methylheptadecane & 15.18 & 3.71 \\
\hline & 3 & 2,6,11,15-Tetramethylhexadecan- & 17.55 & 8.44 \\
\hline & 4 & Pentanoic acid, 5-hydroxy-,2,4-di-t-butylphenyl esters & 17.83 & 3.87 \\
\hline & 5 & 2-Methylheptadecane- & 18.13 & 11.68 \\
\hline & 6 & 9-eicosene $(\mathrm{E})$ & 18.78 & 16.82 \\
\hline & 7 & Dichloroacetic acid, heptadecyl ester & 21.15 & 6.42 \\
\hline & 8 & Palmitic acid, methyl ester & 22.60 & 18.89 \\
\hline & 9 & 9-Tricosene. (Z)- & 23.28 & 9.74 \\
\hline & 10 & Linoleic acid & 24.35 & 14.08 \\
\hline \multirow{8}{*}{ (SH8) } & 1 & 2.4-Decadienal & 15.16 & 3.82 \\
\hline & 2 & 9-Eicosene. (E)- & 18.77 & 16.53 \\
\hline & 3 & Dichloroacetic acid, heptadecyl ester & 21.14 & 16.84 \\
\hline & 4 & Palmitic acid, methyl ester & 22.60 & 24.91 \\
\hline & 5 & 1-Octadecanol & 23.58 & 13.23 \\
\hline & 6 & Oleic acid, methyl ester & 24.39 & 5.57 \\
\hline & 7 & Stearic acid, methyl ester & 24.62 & 10.49 \\
\hline & 8 & 9-Hexacosene & 25.23 & 8.59 \\
\hline
\end{tabular}

RT, retention time; area, percentage obtained by electronic integration measurement using a mass detector RT trace. 
TABLE 4: Acetone extract and its fractions identification by HPLCDAD.

\begin{tabular}{|c|c|c|c|}
\hline Sample & $\mathrm{RT}(\min )$ & Area (\%) & Compound \\
\hline \multirow{13}{*}{ Extract (FA) } & 2.92 & 23.50 & Gallic acid \\
\hline & 2.97 & 2.03 & Ascorbic acid \\
\hline & 3.74 & 4.85 & ND \\
\hline & 3.80 & 3.65 & ND \\
\hline & 5.40 & 3.82 & Thymoquinone \\
\hline & 19.22 & 4.95 & Rutin \\
\hline & 22.28 & 8.45 & Naringenin \\
\hline & 27.74 & 8.42 & Quercetin \\
\hline & 32.54 & 2.03 & Kaempferol \\
\hline & 42.42 & 13.20 & Cysteine \\
\hline & 42.50 & 3.73 & ND \\
\hline & 42.60 & 13.27 & Apigenin \\
\hline & 42.73 & 8.05 & ND \\
\hline Fraction (SA1) & 2.92 & 98.9 & Gallic acid \\
\hline \multirow{3}{*}{ Fraction (SA2) } & 2.92 & 25.8 & Gallic acid \\
\hline & 5.40 & 12.3 & Thymoquinone \\
\hline & 42.60 & 73.5 & Apigenin \\
\hline \multirow{2}{*}{ Fraction (SA3) } & 2.92 & 5.36 & Gallic acid \\
\hline & 39.92 & 79.83 & Catechol \\
\hline Fraction (SA4) & 22.28 & 88.7 & Naringenin \\
\hline \multirow{2}{*}{ Fraction (SA6) } & 3.74 & 10.74 & ND \\
\hline & 42.73 & 86.72 & \\
\hline \multirow{2}{*}{ Fraction (SA7) } & 2.97 & 13.9 & Ascorbic acid \\
\hline & 42.42 & 82.17 & Cysteine \\
\hline \multirow{2}{*}{ Fraction (SA8) } & 3.80 & 25.21 & ND \\
\hline & 42.50 & 72.01 & \\
\hline \multirow{3}{*}{ Fraction (SA11) } & 19.22 & 4.80 & Rutin \\
\hline & 27.74 & 7.65 & Quercetin \\
\hline & 42.24 & 12.3 & L-Histidine \\
\hline
\end{tabular}

$\mathrm{ND}$, none determined; RT, retention time; area, percentage obtained by electronic integration measurement using a mass detector RT trace.

The acetone extract (FA) and its fractions (SA1) and (SA11) did not show any activity against Gram-positive or Gram-negative bacteria (Table 5). While the other acetone fractions did have antibacterial properties, they were lower than those obtained with tetracycline $1 \mathrm{mg} / \mathrm{mL}$. (SA4), (SA8), and (SA10) had medium activity towards Grampositive bacteria (9-12 $\mathrm{mm}$ ), and fractions (SA5) and (SA6) had low activity against both Gram-positive and -negative bacteria $(9-10 \mathrm{~mm})$. (SA2) and (SA3) had high activity towards $S$. aureus $(13 \mathrm{~mm}$ ) and low activity towards E. coli (9$10 \mathrm{~mm}$ ) while (SA8) and (SA10) presented a high inhibitory effect on L. innocua $(12 \mathrm{~mm})$. (SA7) was highly active towards all bacteria strains $(12-13 \mathrm{~mm})$.

3.6. Determination of Antibacterial Activity by Quantitative Assay. Antibacterial activity of fractions (FH), (SH1), (SH2), (SA7), and (SA8) of Nigella sativa (NS) were selected for their inhibitory effect previously determined and on the quantity limit. The fractions were tested for their inhibition of biomass growth of pathogenic bacteria in $\mathrm{MH}$ Broth, and the results obtained are reported in Figure 3. These results showed that the higher the concentration of the fraction, the
TABLE 5: Antibacterial activity of hexane ((FH) and (SH (1-9)) and acetone ((FA and SA (1-11)) fractions obtained from $N$. sativa seeds*.

\begin{tabular}{|c|c|c|c|c|}
\hline \multirow[b]{2}{*}{$\begin{array}{l}\text { Fractions of hexane } \\
\text { extract }\end{array}$} & \multicolumn{2}{|c|}{ Gram- } & \multicolumn{2}{|c|}{ Gram+ } \\
\hline & $\begin{array}{l}E \text {. } \\
\text { coli }\end{array}$ & $\begin{array}{c}P . \\
\text { aeruginosa }\end{array}$ & $\begin{array}{c}L . \\
\text { innocua }\end{array}$ & $\begin{array}{c}\text { S. } \\
\text { aureus }\end{array}$ \\
\hline$(\mathrm{FH})$ & 11 & ND & 12 & 10 \\
\hline (SH1) & 8 & 10 & 11 & ND \\
\hline (SH2) & 8 & ND & 11 & 10 \\
\hline (SH3) & ND & ND & 8 & 10 \\
\hline (SH4) & 15 & ND & 12 & 9 \\
\hline (SH5) & 10 & 9 & ND & ND \\
\hline (SH6) & ND & ND & 12 & 8 \\
\hline (SH7) & ND & ND & 8 & 9 \\
\hline (SH8) & 9 & ND & ND & 11 \\
\hline DMSO $(1 \mathrm{mg} / \mathrm{mL})$ & - & - & - & - \\
\hline \multirow[t]{2}{*}{$\begin{array}{l}\text { Tetracycline (1 mg/ } \\
\mathrm{mL})\end{array}$} & 30 & 30 & 30 & 30 \\
\hline & \multicolumn{2}{|c|}{ Gram - } & \multicolumn{2}{|c|}{ Gram+ } \\
\hline $\begin{array}{l}\text { Fractions of acetone } \\
\text { extract }\end{array}$ & $\begin{array}{l}E . \\
\text { coli }\end{array}$ & $\begin{array}{c}P . \\
\text { aeruginosa }\end{array}$ & $\begin{array}{c}\text { L. } \\
\text { innocua }\end{array}$ & $\begin{array}{c}S . \\
\text { aureus }\end{array}$ \\
\hline$(\mathrm{FA})$ & ND & ND & ND & ND \\
\hline (SA1) & ND & ND & ND & ND \\
\hline (SA2) & 10 & ND & ND & 13 \\
\hline (SA3) & 9 & ND & ND & 13 \\
\hline (SA4) & ND & $\mathrm{ND}$ & 10 & 9 \\
\hline (SA5) & ND & 9 & 10 & 10 \\
\hline (SA6) & 10 & ND & ND & 9 \\
\hline (SA7) & 10 & 13 & 12 & 11 \\
\hline (SA8) & ND & ND & 12 & 10 \\
\hline (SA10) & ND & ND & 12 & ND \\
\hline (SA11) & ND & ND & ND & $\mathrm{ND}$ \\
\hline $\begin{array}{l}\text { Tetracycline }(1 \mathrm{mg} / \\
\mathrm{mL})\end{array}$ & 30 & 30 & 30 & 30 \\
\hline DMSO $(1 \mathrm{mg} / \mathrm{mL})$ & - & - & - & - \\
\hline
\end{tabular}

${ }^{*}$ Values are in $\mathrm{mm}$ (inhibition diameter); ND, not detected; DMSO, dimethyl sulfoxide.

greater the inhibition in biomass growth of the targets ( $E$. coli, P. aeruginosa, and L. innocua).

Every curve was labelled at the end of its evolution. On the third step, E. coli was illustrated with the dispersion of the concentration curves (Figures 3(a), 3(c), 3(f), and 3(i)), while $P$. aeruginosa grouped and converged to a precise point (Figures 3(b), 3(d), 3(e), and 3(g)). L. innocua curves evolved in similar fashion (Figure $3(\mathrm{~h})$ ). The gap between the control and the fractions against E. coli widened over time. As time increased, the gap widened and activity increased. This traduces the positive evolution of activity on E. coli strain. For $P$. aeruginosa, the opposite trend was observed. All curves of both the lowest and highest activity converged to a precise point at an average time. In the case of Listeria strain, the activities of fractions were maintained constant for 45 minutes.

If we compare the evolution of the fractions' activities based on time, the optical density decreased when the concentrations of fractions increased for all bacterial strains. At the end of the third step ( $t=45 \mathrm{~min})$, optical density varied from two to three times for E. coli, two to five times for $P$. aeruginosa, and four times for Listeria. The antibacterial activity sequences were arranged as follows: 


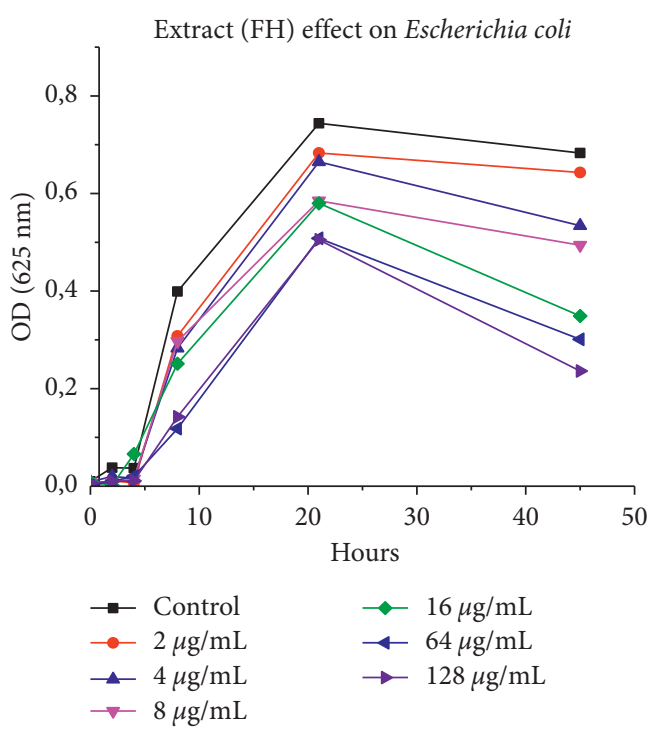

(a)

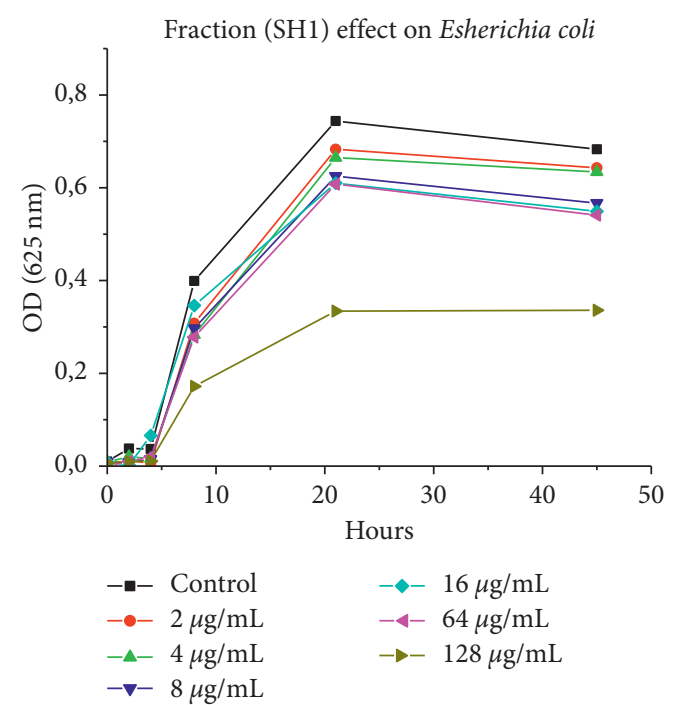

(c)

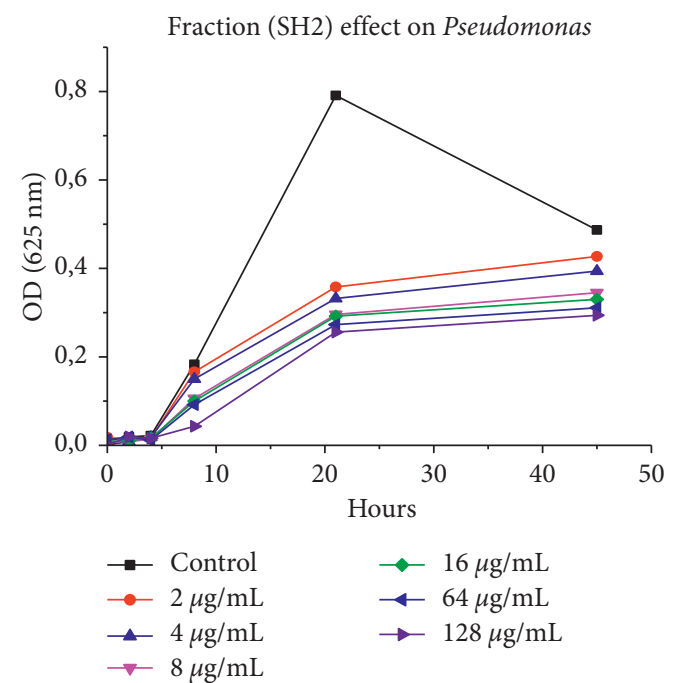

(e)

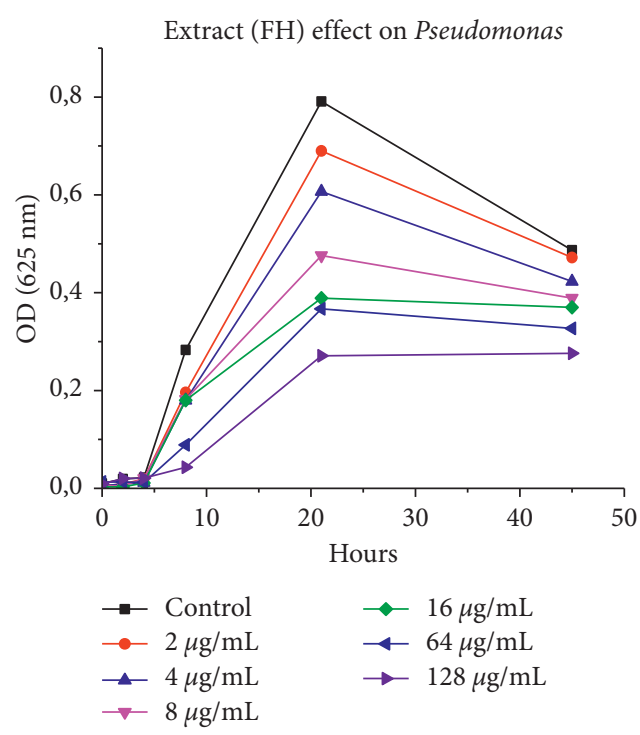

(b)

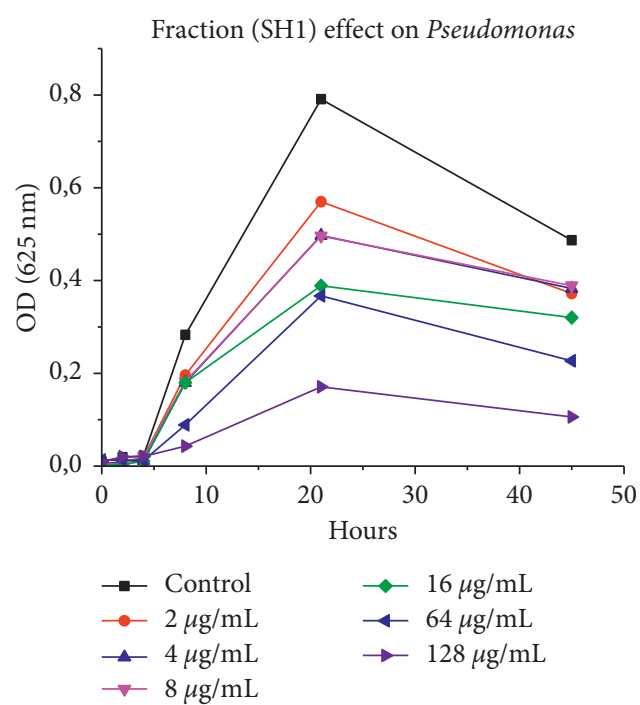

(d)

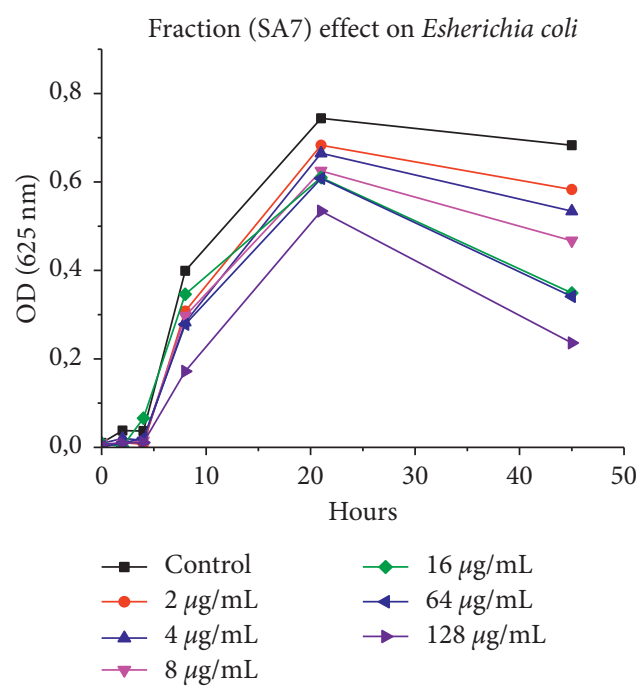

(f)

Figure 3: Continued. 


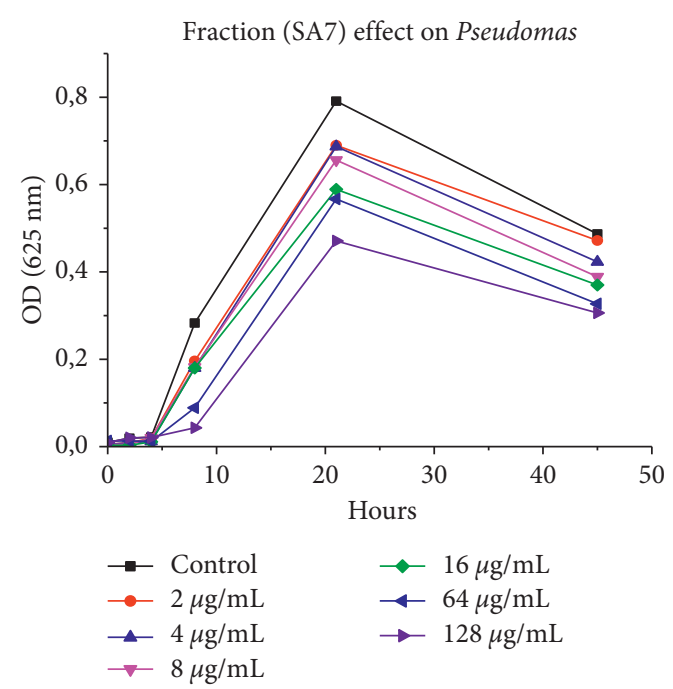

(g)

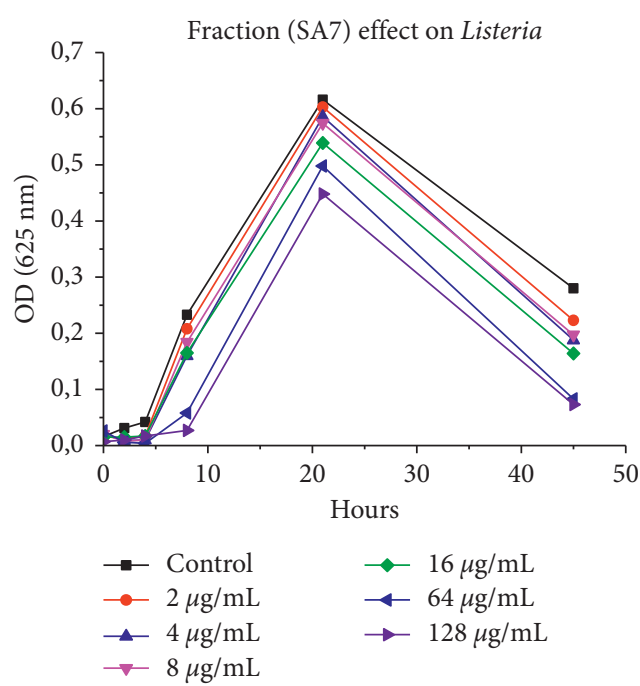

(h)

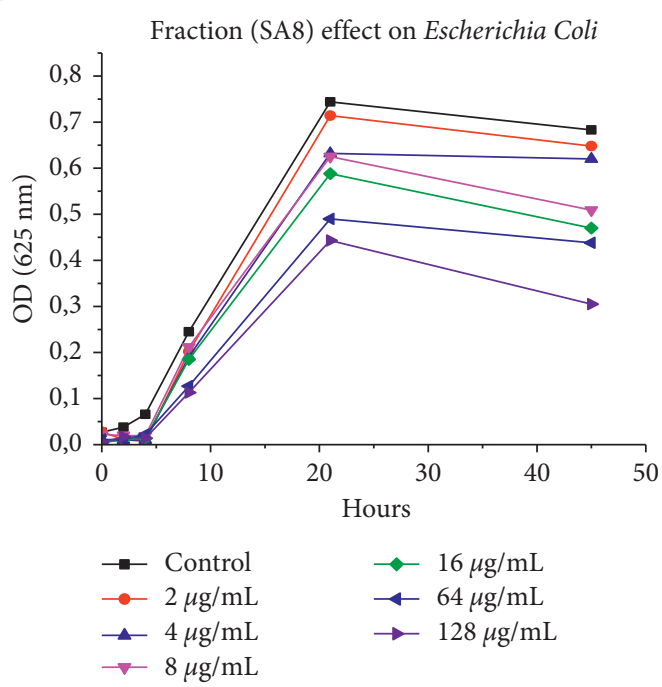

(i)

FIGURE 3: The biomass growth variation of target bacterial strains in the presence of hexane and acetone fractions.

$(\mathbf{F H})>($ SA7 $)>($ SA8 $)>($ SH1 $)$ for Escherichia coli $($ SH1 $)>($ FH $)>($ SA3 $)>($ SA7 $)>$ for Pseudomonas

3.7. Essential Oil Antibacterial Activity: Microdilution Test. The NS essential oil was tested on three pathogenic strains (Staphylococcus aureus (SA), Bacillus cereus (BC), and Escherichia coli (EC)) with concentrations from 500 to $1000 \mu \mathrm{g} / \mathrm{mL}$ (Table 6). The minimum inhibitory concentration (MIC) values obtained were $960 \mu \mathrm{g} / \mathrm{mL}$ for SA, $500 \mu \mathrm{g} /$ $\mathrm{mL}$ for $\mathrm{BC}$, and $680 \mu \mathrm{g} / \mathrm{mL}$ for EC. Those values of antibacterial activity of Nigella sativa essential oil were average.

3.8. Antifungal Activity. Hexane and acetone extracts and their fractions were tested on Candida pelliculosa (Table 7). The compounds presented low, medium, and high activity. Acetone extract (FA) and fraction (SA7) had high activity but not comparable to the reference cycloheximide $0.01 \%$. The fractions (SH1), (SH2), (SH3), and (SA3) presented a high antifungal activity. For the other hexane fractions, the antifungal effects were medium or low. Hexane extract gave low activity, but generated fractions were more active. Acetone extract generated fraction (SA7) that showed the same high activity as the extract; however, the other fractions were less active than their source (FA).

3.9. Essential Oil Antifungal Activity: Microdilution Test. NS essential oil had a minimum fungal concentration equal to $8 \mu \mathrm{g} / \mathrm{mL}$ against Candida albicans strains ( $\mathrm{Ta}-$ ble 8). The MIC was the lowest that was found in our fungal study. In general, Nigella sativa had high antifungal effect that makes the essential oil a specific active antifungal. 
TABle 6: Determination of essential oil MIC towards antibacterial strains.

\begin{tabular}{ccccccccc}
\hline & $1000 \mu \mathrm{g} / \mathrm{mL}$ & $970 \mu \mathrm{g} / \mathrm{mL}$ & $960 \mu \mathrm{g} / \mathrm{mL}$ & $950 \mu \mathrm{g} / \mathrm{ml}$ & $700 \mu \mathrm{g} / \mathrm{mL}$ & $680 \mu \mathrm{g} / \mathrm{mL}$ & $500 \mu \mathrm{g} / \mathrm{mL}$ & $\mathrm{Control}$ \\
\hline $\mathrm{SA}$ & - & - & - & - & + & - & + & + \\
$\mathrm{BC}$ & - & - & - & - & - & - & + \\
$\mathrm{EC}$ & - & & & - & - & + & + \\
\hline
\end{tabular}

SA, Staphylococcus aureus; BC, Bacillus cereus; EC, Escherichia coli.

TAвLE 7: Inhibition diameters $(\mathrm{mm})$ of hexane and acetone fractions obtained against Candida pelliculosa.

\begin{tabular}{|c|c|}
\hline Fractions from hexane extract samples & Candida pelliculosa \\
\hline Hexane extract $(\mathrm{FH})$ & 8 \\
\hline$(\mathrm{SH} 1)$ & 13 \\
\hline (SH2) & 12 \\
\hline (SH3) & 12 \\
\hline (SH4) & 10 \\
\hline (SH5) & 8 \\
\hline (SH6) & 10 \\
\hline (SH7) & 10 \\
\hline (SH8) & 11 \\
\hline DMSO & ND \\
\hline Cycloheximide $0.01 \%$ & 24 \\
\hline Fractions from acetone extract samples & Candida pelliculosa \\
\hline Acetone extract (FA) & 18 \\
\hline (SA1) & 10 \\
\hline (SA2) & 11 \\
\hline (SA3) & 12 \\
\hline (SA4) & 10.9 \\
\hline (SA5) & 11 \\
\hline (SA6) & 8 \\
\hline (SA7) & 19 \\
\hline (SA8) & 8 \\
\hline$(\mathrm{SA} 10)$ & 9 \\
\hline (SA11) & 8 \\
\hline Cycloheximide $0.01 \%$ & 24 \\
\hline DMSO & ND \\
\hline
\end{tabular}

$\mathrm{ND}$, none determined.

TABLE 8: Determination of essential oil MIC towards antifungal strain.

\begin{tabular}{lccccccc}
\hline Concentration $(\mu \mathrm{g} / \mathrm{mL})$ & 32 & 16 & 8 & 4 & 2 & 1 & Control \\
\hline Candida albicans & - & - & - & + & + & + & + \\
\hline
\end{tabular}

\section{Discussion}

Solvent polarity had an impact on the extracted compounds. Successive extraction was performed in order to separate the extracted compounds based on polarity. We only used hexane and acetone extracts in this study, partly due to their polarity difference. Hexane solvent is responsible for the extraction of lipophilic components such as terpenes and sterols, and acetone extracted polar compounds such as flavonoids and polyphenols. With a yield value of $34.2 \%$, NS seeds are high in fat. Many studies reported hexane extract was the most abundant extract from NS [26-28], while acetone extract had a yield of only $2.5 \%$ [29].

The essential oil had a low yield when it is directly extracted from NS seeds $(0.18 \%)$, that is the reason why hydrodistillation was necessary for the hexane extract. Indeed, Singh et al. had a similar yield of 1.2\% [30]. Volatile oil yields of $0.4 \%$ to $0.44 \%$ [31] were reported from hexane extracts by hydrodistillation and with supercritical $\mathrm{CO}_{2}$ method, a yield of $0.1 \%$ to $0.3 \%$ [32] based on NS seeds origin.

On the esterified hexane extract, the major components were fatty acids $[32,33]$, both unsaturated fatty acids such as linoleic and oleic acids and saturated fatty acids such as palmitic acid [26].

Essential oil composition depends directly on its geographical origin, climate factors, extraction method, and the temperature conditions. As a result, the composition of NS essential oil could vary from a study to another. In the literature, Burits and Bucar [31] reported alphapinene and beta. Thujene constituted $0.15 \%$, carvacrol $8.50 \%$, and thymoquinone $35.30 \%$. For Wajs et al. [34], the composition was $3 \%$ carvacrol and $60 \% \alpha$-cymene and thymoquinone was less than $0.05 \%$. The essential oil from NS Indian seeds is the 
most similar to those seen in this study with a composition of $36.2 \% \beta$-cymene, $11.27 \%$ thymoquinone, $10.03 \% \alpha$-thujene, $2.12 \%$ carvacrol, and $6.3 \%$ longifolene [30]. The characterization of Iranian commercial NS essential oil had carvacrol at $2.2 \%$, thymoquinone at $2 \%, \beta$-cymene at $41.7 \%$, longifolene at 3.3\%, and terpinol at $1.9 \%$ [35]. The composition differences could be the result of a p-cymene transformation. In fact, even differences in the composition of essential oils harvested from the same geographical origin with the same extraction method are possible [36] because oxygen can cause transformation of $\mathrm{p}$-cymene into many derivative compounds.

In hexane extract fractions, many compounds were found in multiple fractions. Repetitive acquisition of constituents is a result of not only the abundance of fatty acids but also the difficulties associated with their migration through the chromatography column. Some less common compounds in hexane extracts are reported in Table 3 such as eicosadien acid, 9.12-octadecanoic acid, and pentanone dimethyl [37, 38].

The characterization of acetone extract was in line with the chemical composition reported by Mechraoui et al. [17]. In addition, the identification of acetone extract fractions was consistent with our previous studies [7] and the fractions contained compounds with interesting biological activities [39-41].

Hexane extract and isolated linoleic acid were both more active against Gram-positive bacteria [32, 42]. Fraction (SH4) had the highest antibacterial effect on $E$. coli and $L$. innocua. Harzallah reported the inhibition zone diameter on L. innocua and E. coli were, respectively, $7 \mathrm{~mm}$ and $4.66 \mathrm{~mm}$ [43]. The antimicrobial activity of fractions ( $\mathrm{SH} 4)$ and ( $\mathrm{SH} 7)$ relied on compounds 17 pentatriacontene (50\%) and hexadecane which confirmed their bioactivity [44, 45].

Acetone extract (FA) had low activity towards Staphylococcus aureus and E. coli [17]. However, chicks fed NS acetone extract subproducts showed high activity towards $E$. coli in the feces [46]. Apigenin had a low antibacterial effect [47], with thymoquinone being the active part of the fraction (SA2) [48]. (SA3) was identified as catechol, a phenolic compound with interesting antibacterial activity towards Gram-positive bacteria [49] and (SA7) activity was a result of ascorbic acid and cysteine which are well known for their antibacterial properties [50, 51]. Also, acetone fraction (SA10) was active because it contained essentially rutin that resulted in antibacterial activity towards Gram-positive and Gram-negative bacteria [52-54].

The best antibacterial activity was attributed to the fraction (SA7) towards L. innocua and fraction (SH1) towards $P$. aeruginosa. Hexane extract had antibacterial activity against Gram-positive bacteria $[55,56]$ because of thymoquinone, p-cymene, and carvacrol, all good antimicrobials [57, 58]. In many studies, the antibacterial activity was attributed to the presence of fatty acids such as oleic, linoleic, and palmitic acids in the hexane extract [59-61]. After separation, the antibacterial activity of fraction ( $\mathrm{SH} 1)$ was noticed because it contained fatty acid components such as palmitic and heptadecanoic acids [44]. Fraction (SH2) activity is almost entirely due to palmitic acid (50\%), linoleic acid (17\%), and heptadecanoic acid $(16.35 \%)$. These compounds were reported as antimicrobials [44, 62]. The activity of acetone fraction (SA7) is explained by the presence of cysteine and ascorbic acid. In fact, ascorbic acid inhibits E. coli [50] and cysteine inhibits L. innocua and S. aureus $[51,63]$. The inhibitory activity of strains by fraction (SA7) could then be caused by the intervention of one or both constituents or the result of a synergic relationship between cysteine and ascorbic acid [64].

Our essential oil MIC values for S. aureus and E. coli were similar to those obtained by Ainane et al. [65], with a MIC value of $964 \mu \mathrm{g} / \mathrm{mL}$ towards $S$. aureus and a MIC equal to $676 \mu \mathrm{g} / \mathrm{mL}$ towards E. coli. Our results for Bacillus cereus were similar to Landa et al. [66] $(\mathrm{MIC}=512 \mu \mathrm{g} / \mathrm{mL})$ but different from S. aureus $(\mathrm{MIC}=512 \mu \mathrm{g} / \mathrm{mL})$ and E. coli (MIC $>1024 \mu \mathrm{g} / \mathrm{mL})$.

The constituents of the hexane extract are hydrophobic allowing for strong interactions with the microbial membrane. As a result, alterations to the microbial membrane increases permeability and allows high consumption of the active agent by microbial cells [67].

With palmitic and heptadecanoic acids, (SH2) and (SH3) were more active than hexane extract that contains linoleic acid at $80 \%$ [62]. Machraoui et al. reported modest activity by acetone extract against $C$. albicans [17]. (SA2) had medium activity and contained mostly apigenin. In fact, apigenin inhibited A. tenuissima [68] which was also active through the membrane perturbation and biofilm reduction which changes Candida physiology $[69,70]$.

(SA3) caused high antifungal activity. Fungal strains are sensitive to catechol; in consequence, its antifungal activity was elevated [49, 71]. Moreover, (SA7) was the most active fraction that even exceeded the acetone extract. (SA7) contained cysteine which changes the morphology of fungal colonies by creating a structural modification that generates nuclear degradation [72, 73].

The chemical mechanism for the essential oil is difficult to explain due to its complexity. It is possible that every single component has its own mechanism of action. The most abundant compounds describe the essential oil efficacy. For example, terpenes and hydrocarbons have an inhibitory effect on bacteria strains. In fact, the lipophilic propriety of skeletal hydrocarbons and hydrophilic properties of alcohol, aldehydes, and ketones have a positive impact on antimicrobial activity [74, 75].

Thymoquinone and carvacrol in the essential oil had minimal antimicrobial activity $[58,65]$. Hydrocarbons such as lilac aldehyde D in NS essential oil had high antimicrobial activity likely because conjugated aldehyde groups with double carbon-carbon bonds are highly electronegative. Suggesting that increasing electronegativity would increase antimicrobial activity [76, 77].

The presence of thymol in essential oil could show a medium activity against bacterial strains [78]. Terpenes such as $\alpha$-pinene, $\beta$-pinene, and $\gamma$-terpinene also present high antibacterial activity towards Gram-positive bacteria and medium activity towards Gram-negative bacteria $[30,79,80]$. 


\section{Conclusion}

Column chromatography was used to separate hexane and acetone extracts into their purified fractions. Characterization based on GC-MS and HPLC-DAD showed the nature of the extracts and fractions and exposed links between antimicrobial activity and chemical composition.

Hexane and acetone extracts and their fractions had antibacterial and antifungal activities. Most fractions were more active against Gram-positive than Gram-negative bacteria. However, the (SH4) was active towards Gramnegative bacterial strains, and (SA7) had the highest antifungal activity.

The microdilution method was proceeded on NS essential oil for the determination of antibacterial and antifungal activities through quantification by MIC. Our results show that antifungal activity is more important than antibacterial activity.

Antimicrobial activity was a consequence of separated compounds as witnessed by comparing activity before and after separation. This may be a result of a unique isolated compound in the fraction or several compounds that react simultaneously or synergistically, meaning two compounds would individually have low activities, but when combined within the same fraction, their activity would increase. In summary, Nigella sativa L. extracts and fractions are interesting antimicrobials that could be exploitable in therapy and industry.

The next step is to test the active antimicrobial fractions against "sensitive" foods to determine if Nigella sativa can be used for food preservation.

\section{Abbreviations}

\begin{tabular}{|c|c|}
\hline (FH): & Hexane extract \\
\hline (FA): & Acetone extract \\
\hline $\begin{array}{l}(\mathrm{SH} \\
(1-8)):\end{array}$ & Hexane extract separated fractions \\
\hline $\begin{array}{l}(\mathrm{SA} \\
(1-11)):\end{array}$ & Acetone extract separated fractions \\
\hline GC-MS: & Gas chromatography-mass spectroscopy \\
\hline HPLC- & High performance liquid chromatography \\
\hline DAD: & coupled with diode array detector \\
\hline MIC: & Minimal inhibition concentration. \\
\hline
\end{tabular}

\section{Data Availability}

All data used to support the finding of this study are available online and from the corresponding author upon request.

\section{Conflicts of Interest}

The authors declare that they have no conflicts of interest.

\section{References}

[1] A. Majeed, Z. Muhammad, H. Ahmad et al., "Nigella sativa L.: uses in traditional and contemporary medicines-an overview," Acta Ecologica Sinica, vol. 41, no. 4, pp. 253-258, 2021.
[2] A. Kazmi, M. A. Khan, and H. Ali, "Biotechnological approaches for production of bioactive secondary metabolites in Nigella sativa: an up-to-date review," International Journal of Secondary Metabolite, vol. 6, no. 2, pp. 172-195, 2019.

[3] V. Kurkin, A. Mubinov, H. Avdeeva, and T. Ryazanova, "Comparative research of fatty acid composition and volatile components of fatty oils from seeds of nigella sativa and argania spinosa," Research Journal of Pharmacy and Technology, vol. 14, no. 3, pp. 1586-1590, 2021.

[4] O. H. Nautiyal, Fruit Oils: Chemistry and Functionality Black Seed Nigella Sativa, Springer, Berlin, Germany, 2019.

[5] M. S. Iqbal, A. Ghafoor, M. Akbar, S. Akhtar, S. Fatima, and E. H. Siddqui, "Genetic variation and path analysis for yield and other agronomic traits in nigella sativa l. germplasm," Bangladesh Journal of Botany, vol. 48, no. 3, pp. 521-527, 2019.

[6] S. Gaur, R. Srivastava, S. Gaur, R. Bhardwaj, and Khanchandani, "Medicinal and therapeutically potential of nigella sativa," International Journal of Medical and Biomedical Studies, vol. 1, no. 5, p. 423, 2017.

[7] S. Tiji, O. Benayad, B. Mohamed, I. El Mounsi, and M. Mimouni, "Phytochemical profile and antioxidant activity of Nigella Sativa L growing in Morocco," Science World Journal, vol. 2021, Article ID 6623609, 12 pages, 2021.

[8] S. Tiji, M. Bouhrim, M. Addi et al., "Linking the phytochemicals and the $\alpha$-glucosidase and $\alpha$-amylase enzyme inhibitory effects of Nigella sativa seed extracts," Foods, vol. 10, p. $1818,2021$.

[9] C. Vlachojannis, S. Chrubasik-Hausmann, E. Hellwig, K. Vach, and A. Al-Ahmad, "Activity of preparations from Spilanthes oleracea, propolis, Nigella sativa, and black garlic on different microorganisms involved in oral diseases and on total human salivary bacteria: a pilot study," Phytotherapy Research, vol. 32, no. 10, pp. 1992-2001, 2018.

[10] S. N. Bakal, S. Bereswill, and M. M. Heimesaat, "Finding novel antibiotic substances from medicinal plants-antimicrobial properties of Nigella sativa directed against multidrug resistant bacteria," European Journal of Microbiology and Immunology, vol. 7, no. 1, pp. 92-98, 2017.

[11] M. Mekhemar, Y. Hassan, and C. Dörfer, "Nigella sativa and thymoquinone: a natural blessing for periodontal therapy," Antioxidants, vol. 9, no. 12, pp. 1-19, 2020.

[12] B. T. Petrujkić, R. C Beier, H He et al., "Nigella sativa L. as an alternative antibiotic feed supplement and effect on growth performance in weanling pigs," Journal of the Science of Food and Agriculture, vol. 98, no. 8, pp. 3175-3181, 2018.

[13] A. Mouwakeh, Á. Telbisz, G. Spengler, C. Mohácsi-farkas, and G. Kiskó, "Antibacterial and resistance modifying activities of nigella sativa essential oil and its active compounds against listeria monocytogenes," In Vivo, vol. 32, no. 4, pp. 737-743, 2018.

[14] K. Bensiameur-Touati, G. Kacimi, E.-M. Haffaf, S. Berdja, and S. Aouichat-Bouguerra, "In vivo subacute toxicity and antidiabetic effect of aqueous extract of Nigella sativa," EvidenceBased Complementary and Alternative Medicine, vol. 2017, Article ID 8427034, 13 pages, 2017.

[15] P. Bayati, H. Karimmojeni, and J. Razmjoo, "Changes in essential oil yield and fatty acid contents in black cumin (Nigella sativa L.) genotypes in response to drought stress," Industrial Crops and Products, vol. 155, Article ID 112764, 2020.

[16] J. Dobaria and S. Raval, "Separation of phytochemicals from peucedanum nagpurense by using separation of phytochemicals from peucedanum," Cell and Tissue Research, vol. 15, pp. 5275-5281, 2016. 
[17] O. Mechraoui, S. Ladjel, and M. S. Nedjimi, "Determination of polyphenols content, antioxidant and antibacterial activity of Nigella Sativa L. seed polyphenolic extracts," Scientific Study and Research: Chemistry and Chemical Engineering, Biotechnology, Food Industry, vol. 19, no. 4, pp. 411-421, 2018.

[18] F. Abrigach, B. Bouchal, O. Riant et al., "New N, N, N', N'tetradentate pyrazoly agents: synthesis and evaluation of their antifungal and antibacterial activities," Medicinal Chemistry, vol. 12, no. 1, pp. 83-89, 2016.

[19] M. Grech-Baran and A. Pietrosiuk, "Artemisia species in vitro cultures for production of biologically active secondary metabolites," BioTechnologia, vol. 4, pp. 371-380, 2012.

[20] V. Guérin-Faublée and G. Carret, "L'antibiogramme: principe, méthodologie intérêt et limites," Journées nationales, vol. 17, pp. 5-12, 1999.

[21] A. J. Hayes and B. Markovic, "Toxicity of australian essential oil Backhousia citriodora (Lemon myrtle). Part 1. Antimicrobial activity and in vitro cytotoxicity," Food and Chemical Toxicology, vol. 40, no. 4, pp. 535-543, 2002.

[22] J. Allegrini, M. S. Bouchberg, and H. Maillols, "Emulsions d'huiles essentielles, fabrication et application en microbiologie," Société Pharm. Montpellier, vol. 33, pp. 73-86, 1973.

[23] I. Shabina, A. Muhammad, H. Muhammad Qasim, and A. Mudassir, "Phytochemical analysis of Nigella sativa and its antibacterial activity against clinical isolates identified by ribotyping," International Journal of Agriculture and Biology, vol. 15, no. 6, pp. 1151-1156, 2013.

[24] L. Barros, R. C. Calhelha, J. A. Vaz, I. C. F. R. Ferreira, P. Baptista, and L. M. Estevinho, "Antimicrobial activity and bioactive compounds of Portuguese wild edible mushrooms methanolic extracts," European Food Research and Technology, vol. 225, no. 2, pp. 151-156, 2007.

[25] A. Chebaibi, Z. Marouf, F. Rhazi-Filali, M. Fahim, and A. EdDra, "Évaluation du pouvoir antimicrobien des huiles essentielles de sept plantes médicinales récoltées au Maroc," Phytothérapie, vol. 14, no. 6, pp. 355-362, 2016.

[26] A. Khoddami, H. M. Ghazali, A. Yassoralipour, Y. Ramakrishnan, and A. Ganjloo, "Physicochemical characteristics of nigella seed (Nigella sativa L.) oil as affected by different extraction methods," Journal of the American Oil Chemists' Society, vol. 88, no. 4, pp. 533-540, 2011.

[27] B. Matthäus, "Antioxidant activity of extracts obtained from residues of different oilseeds," Journal of Agricultural and Food Chemistry, vol. 50, no. 12, pp. 3444-3452, 2002.

[28] L. F. D’Antuono, A. Moretti, and A. F. S. Lovato, "Seed yield, yield components, oil content and essential oil content and composition of Nigella sativa L. and Nigella damascena L," Industrial Crops and Products, vol. 15, no. 1, pp. 59-69, 2002.

[29] T. Sun and C. T. Ho, "Antioxidant activities of buckwheat extracts," Food Chemistry, vol. 90, no. 4, pp. 743-749, 2005.

[30] G. Singh, P. Marimuthu, C. S. De Heluani, and C. Catalan, "Chemical constituents and antimicrobial and antioxidant potentials of essential oil and acetone extract of Nigella sativa seeds," Journal of the Science of Food and Agriculture, vol. 85, no. 13, pp. 2297-2306, 2005.

[31] M. Burits and F. Bucar, "Antioxidant activity of Nigella sativa essential oil," Phytotherapy Research, vol. 328, no. 13, pp. 323-328, 2000.

[32] A. Piras, A. Rosa, B. Marongiu et al., "Chemical composition and in vitro bioactivity of the volatile and fixed oils of Nigella sativa L. extracted by supercritical carbon dioxide," Industrial Crops and Products, vol. 46, pp. 317-323, 2013.

[33] S. Gharby, H. Harhar, D. Guillaume et al., "Chemical investigation of Nigella sativa L. seed oil produced in Morocco,"
Journal of the Saudi Society of Agricultural Sciences, vol. 14, no. 2, pp. 172-177, 2015.

[34] A. Wajs, R. Bonikowski, and D. Kalemba, "Composition of essential oil from seeds of Nigella sativa L. cultivated in Poland," Flavour and Fragrance Journal, vol. 23, no. 2, pp. 126-132, 2008.

[35] K. M. Hasanzadeh, M. Ramazanie, and S. Golmohammadzadeh, "Volatile constituents of Nigella sativa L seeds," Oriental Journal of Chemistry, vol. 16, no. 3, 2000.

[36] C. Turek and F. C. Stintzing, "Stability of essential oils: a review," Comprehensive Reviews in Food Science and Food Safety, vol. 12, no. 1, pp. 40-53, 2013.

[37] H. Ekowati, E. Prasasti, and U. Rastuti, "The active fraction from Nigella sativa and its activity against T47D cell line," Indonesian Journal of Chemistry, vol. 11, no. 3, pp. 217-222, 2011.

[38] D. R. De Oliveira and H. Khater, "The black seed, Nigella sativa (ranunculaceae), for prevention and treatment of hypertension," RPMP Metabolic Disorders Hypertension, vol. 48, pp. 222-242, 2018.

[39] A. A. Mariod, R. M. Ibrahim, M. Ismail, and N. Ismail, "Antioxidant activity and phenolic content of phenolic rich fractions obtained from black cumin (Nigella sativa) seedcake," Food Chemistry, vol. 116, no. 1, pp. 306-312, 2009.

[40] H. M. Abdallah, M. M. Salama, E. H. Abd-Elrahman, and S. A. El-Maraghy, "Antidiabetic activity of phenolic compounds from Pecan bark in streptozotocin-induced diabetic rats," Phytochemistry Letters, vol. 4, no. 3, pp. 337-341, 2011.

[41] C.-L. Hsu and G.-C. Yen, "Phenolic compounds: evidence for inhibitory effects against obesity and their underlying molecular signaling mechanisms," Molecular Nutrition \& Food Research, vol. 52, no. 1, pp. 53-61, 2008.

[42] F. Dilika, P. D. Bremner, and J. J. M. Meyer, “Antibacterial activity of linoleic and oleic acids isolated from Helichrysum pedunculatum: a plant used during circumcision rites," Fitoterapia, vol. 71, no. 4, pp. 450-452, 2000.

[43] H. J. Harzallah, "Chemical composition, antibacterial and antifungal properties of Tunisian Nigella sativa fixed oil," African Journal of Microbiology Research, vol. 6, no. 22, pp. 4675-4679, 2012.

[44] C. N. Diep, N. Tan Binh, and P. V. Ha Lam, "Bioactive compounds from marine fungus Penicillium citrinum strain ND7c by gas chromatography-mass spectrometry," Pharmaceutical Chemistry Journal, vol. 5, no. 1, pp. 211-224, 2018.

[45] K. Rao, P. RabhuKailash, and K. Saikumar, "The GC-MS and antioxidant study of an ayurvedic medicine ayaskriti," International Journal of Pharmaceutical Sciences Review and Research, vol. 42, no. 3, pp. 15-19, 2017.

[46] M. N. Siddiqui, M. T. Islam, M. A. Sayed, and M. A. Hossain, "Effect of dietary supplementation of acetone extracts of Nigella Sativa L. Seeds on serum cholesterol and pathogenic intestinal bacterial count in broilers," The Journal of Animal and Plant Sciences, vol. 25, no. 2, pp. 372-379, 2015.

[47] J. Dong, J. Qiu, J. Wang et al., "Apigenin alleviates the symptoms of Staphylococcus aureuspneumonia by inhibiting the production of alpha-hemolysin," FEMS Microbiology Letters, vol. 338, no. 2, pp. 124-131, 2013.

[48] H. Younus, Molecular and Therapeutic Actions of Thymoquinone: Actions of Thymoquinone, Springer, Berlin, Germany, 2018.

[49] I. Kocaçalişkan, I. Talan, and I. Terzi, “Antimicrobial activity of catechol and pyrogallol as allelochemicals," Zeitschrift fur 
Naturforschung. C, Journal of Biosciences, vol. 61, no. 9-10, pp. 639-642, 2006.

[50] M. Tajkarimi and S. A. Ibrahim, "Antimicrobial activity of ascorbic acid alone or in combination with lactic acid on Escherichia coli O157: H7 in laboratory medium and carrot juice," Food Control, vol. 22, no. 6, pp. 801-804, 2011.

[51] N. Masilela and T. Nyokong, "The interaction of silver nanoparticles with low symmetry cysteinyl metallophthalocyanines and their antimicrobial effect," Journal of Photochemistry and Photobiology A: Chemistry, vol. 255, pp. 1-9, 2013.

[52] N. A. Al-Dhabi, M. V. Arasu, C. H. Park, and S. U. Park, “An up-to-date review of rutin and its biological and pharmacological activities," EXCLI Journal, vol. 14, pp. 59-63, 2015.

[53] S. Al-Majmaie, L. Nahar, G. P. Sharples, K. Wadi, and S. D. Sarker, "Isolation and antimicrobial activity of rutin and its derivatives from ruta chalepensis (rutaceae) growing in Iraq," Records of Natural Products, vol. 13, no. 1, pp. 64-70, 2018.

[54] R. B. Pimentel, C. A. da Costa, P. M. Albuquerque, and S. D. Junior, "Antimicrobial activity and rutin identification of honey produced by the stingless bee melipona compressipes manaosensis and commercial honey," BMC Complementary and Alternative Medicine, vol. 13, p. 151, 2013.

[55] M. T. Salman and R. A. Khan, "Antimicrobial activity of Nigella sativa Linn. seed oil against multi-drug resistant bacteria from clinical isolates," Natural Product Radiance, vol. 7, no. 1, pp. 10-14, 2008.

[56] F. A. Saleh, N. El-Darra, K. Raafat, and I. E. Ghazzawi, "Phytochemical analysis of Nigella sativa L. Utilizing GC-MS exploring its antimicrobial effects against multidrug-resistant bacteria," Pharmacognosy Journal, vol. 10, no. 1, pp. 99-105, 2017.

[57] M. K. Cobourne-Duval, E. Taka, P. Mendonca, D. Bauer, and K. F. A. Soliman, "The antioxidant effects of thymoquinone in activated BV-2 murine microglial cells," Neurochemical Research, vol. 41, no. 12, pp. 3227-3238, 2016.

[58] A. Mouwakeh, A. Kincses, M. Nové et al., "Nigella sativa essential oil and its bioactive compounds as resistance modifiers against Staphylococcus aureus," Phytotherapy Research, vol. 33, no. 4, pp. 1010-1018, 2019.

[59] C. M. B. Pinilla, R. C. S. Thys, and A. Brandelli, "Antifungal properties of phosphatidylcholine-oleic acid liposomes encapsulating garlic against environmental fungal in wheat bread," International Journal of Food Microbiology, vol. 293, pp. 72-78, 2019.

[60] M. Peng, Z. Tabashsum, P. Patel, C. Bernhardt, and D. Biswas, "Linoleic acids overproducing lactobacillus casei limits growth, survival, and virulence of salmonella typhimurium and enterohaemorrhagic Escherichia coli," Frontiers in Microbiology, vol. 9, pp. 1-14, 2018.

[61] X. Zhang, R. Ashby, D. K. Solaiman, J. Uknalis, and X. Fan, "Inactivation of Salmonella spp. and Listeria spp. by palmitic, stearic, and oleic acid sophorolipids and thiamine dilauryl sulfate," Frontiers in Microbiology, vol. 7, pp. 2076-2111, 2016.

[62] P. P. Kumar, S. Kumaravel, and C. Lalitha, "Screening of antioxidant activity, total phenolics and GC-MS study of vitex negundo," African Journal of Biochemistry Research, vol. 4, no. 7, pp. 191-195, 2010.

[63] Y. Kouassi and L. A. Shelef, "Inhibition of listeria monocytogenes by cinnamic acid: possible interaction of the acid with cysteinyl residues," Journal of Food Safety, vol. 18, no. 3, pp. 231-242, 1998.
[64] B. L. Wedzicha and M. A. Brook, "Reaction of sorbic acid with nucleophiles: preliminary studies," Food Chemistry, vol. 31, no. 1, pp. 29-40, 1989.

[65] T. Ainane, M. Talbi, S. Lahsasni, and I. Warad, "Chemical composition and antibacterial activity of essential oil of Nigella sativa seeds from Beni Mellal (Morocco): what is the most important part, essential oil or the rest," Journal of Materials and Environmental Science, vol. 5, no. 6, pp. 2017-2020, 2014.

[66] P. Landa, P. Marsik, J. Havlik, P. Kloucek, T. Vanek, and L. Kokoska, "Evaluation of antimicrobial and anti-inflammatory activities of seed extracts from six nigella species," Journal of Medicinal Food, vol. 12, no. 2, pp. 408-415, 2009.

[67] K. Chaieb, B. Kouidhi, H. Jrah, K. Mahdouani, and A. Bakhrouf, "Antibacterial activity of thymoquinone, an active principle of Nigella sativa and its potency to prevent bacterial biofilm formation," BMC Complementary and Alternative Medicine, vol. 11, no. 1, p. 29, 2011.

[68] U. P. Singh, V. B. Pandey, K. N. Singh, and R. D. N. Singh, "Antifungal activity of some new fiavones and fiavone glycosides of echinops echinatus," Canadian Journal of Botany, vol. 66, no. 9, pp. 1901-1903, 1988.

[69] Y.-S. Jin, "Recent advances in natural antifungal flavonoids and their derivatives," Bioorganic \& Medicinal Chemistry Letters, vol. 29, no. 19, Article ID 126589, 2019.

[70] H. Lee, E. R. Woo, and D. G. Lee, "Apigenin induces cell shrinkage in candida albicans by membrane perturbation," FEMS Yeast Research, vol. 18, no. 1, 2018.

[71] G. L. Farkas and Z. Kiraaly, "Role of phenolic compounds in the physiology of plant diseases and disease resistance," Journal of Phytopathology, vol. 44, no. 2, pp. 105-150, 1962.

[72] N. Hegedüs and F. Marx, "Antifungal proteins: more than antimicrobials?” Fungal Biology Reviews, vol. 26, no. 4, pp. 132-145, 2013.

[73] L. Galgóczy, M. Homa, T. Papp, P. Manikandan, and C. Vágvölgyi, "In vitro antifungal activity of cysteine derivatives and their combinations with antifungal agents against clinically relevant scedosporium species," International Journal of Clinical \& Medical Microbiology, vol. 1, no. 2, pp. 1-5, 2016.

[74] A. Lamba, "Antimicrobial activities of aldehydes and ketones produced during rapid volatilization of biogenic oils," Masters Theses, Missouri University of Science and Technology, vol. 47, pp. 1-72, Rolla, MO, USA, 2007.

[75] R. A. Andersen, T. R. Hamilton-kemp, D. F. Hildebrand, C. T. Mccracken Jr., R. W. Collins, and P. D. Fleming, "Structure-antifungal activity relationships among volatile C6 and C9 aliphatic aldehydes, ketones, and alcohols," Journal of Agricultural and Food Chemistry, vol. 42, no. 7, pp. 1563-1568, 1994.

[76] H. J. D. Dorman and S. G. Deans, "Antimicrobial agents from plants: antibacterial activity of plant volatile oils," Journal of Applied Microbiology, vol. 88, no. 2, pp. 308-316, 2000.

[77] R. A. Holley and D. Patel, "Improvement in shelf-life and safety of perishable foods by plant essential oils and smoke antimicrobials," Food Microbiology, vol. 22, no. 4, pp. 273-292, 2005.

[78] K. El-Tahir PhD and D. M. Bakeet, "The black seed nigella sativa linnaeus-a mine for multi cures: a plea for urgent clinical evaluation of its volatile oil," Journal of Taibah University Medical Sciences, vol. 1, no. 1, pp. 1-19, 2006.

[79] B. Tepe, D. Daferera, A. Sokmen, M. Sokmen, and M. Polissiou, "Antimicrobial and antioxidant activities of the essential oil and various extracts of salvia tomentosa Miller 
(lamiaceae)," Food Chemistry, vol. 90, no. 3, pp. 333-340, 2005.

[80] M. Cristiani, "Interaction of four monoterpenes contained in essential oils with model membranes: implications for their antibacterial activity," Journal of Agricultural and Food Chemistry, vol. 55, pp. 6300-6308, 2007. 